\title{
Pengaruh Harga Diri dan Efikasi Diri Terhadap Kepuasan Kerja Serta Implikasinya Terhadap Kinerja Guru SMP Muhammadiyah Kota Bogor
}

\author{
Saprudin ${ }^{1}$, Brilliantina Indrati ${ }^{2}$, Siti Muladriyani ${ }^{3}$, Asep Supriyatna ${ }^{4}$, Wahyudi ${ }^{5}$ \\ ${ }_{1-5}$ STIA Menara Siswa \\ e-mail : saprudin24bgr@menarasiswa.ac.id, brilliantinaindrati@menarasiswa.ac.id, \\ sitimuladriyani@menarasiswa.ac.id, asepsupriyatna@menarasiswa.ac.id, \\ wahyudi@menarasiswa.ac.id
}

\section{ARTICLES INFORMATION

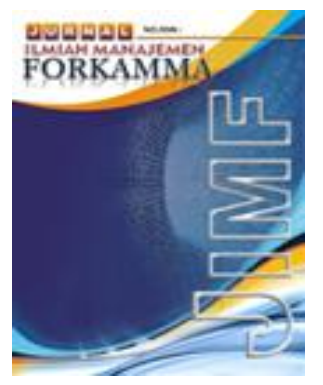 \\ JURNAL ILMIAH MANAJEMEN FORKAMMA}

Vol.4, No.2, Maret 2021 Halaman : $192-204$

C LPPM \& FORKAMMA Prodi Magister Manajemen UNVERSITAS PAMULANG

ISSN (online) : 2599-171X ISSN (print) : : 2598-9545

\section{Keyword: \\ Harga diri; Efikasi Diri; Kepuasan Kerja; Kinerja}

JEL. classification : O15,

\section{Contact Author :}

\section{PRODI MAGISTER MANAJEMEN \& FORKAMMA UNPAM \\ JL.Surya Kencana No.1 Pamulang \\ Tangerang Selatan - Banten \\ Telp. (021) 7412566, Fax (021) 7412491 Email : \\ jurnalforkamma.unpam@gmail.com}

Tujuan penelitian ini adalah untuk mengetahui Pengaruh Harga diri dan Efikasi diri, terhadap Kepuasan Kerja Serta Implikasinya Terhadap Kinerja Guru SMP Muhammadiyah Kota Bogor, sampel dari SMP Muhammadiyah Kota Bogor yang berjumlah 39 orang. Analisis hasil penelitian ini menggunakan analisis jalur. Hasil penelitiannya meliputi Variabel Harga diri secara langsung menentukan perubahan-perubahan variabel Kepuasan Kerja adalah 31,5\%. Jika melalui variabel Efikasi diri pengaruhnya terhadap variabel Kepuasan Kerja sebesar $13,5 \%$. Jadi pengaruh total Harga diri terhadap Kepuasan Kerja adalah sebesar $45,1 \%$. Variabel Efikasi diri memiliki pengaruh secara langsung terhadap Kepuasan Kerja sebesar 16,9\%. Untuk pengaruh tidak langsung, yakni yang melalui variabel Harga diri pengaruhnya terhadap Kepuasan Kerja adalah sebesar 13,6\%. Jadi pengaruh total variabel Efikasi diri terhadap Kepuasan Kerja adalah sebesar 30,5\%.

The purpose of this study was to determine the effect of selfesteem and self-efficacy on job satisfaction and its implications for teacher performance at SMP Muhammadiyah Bogor. This research was conducted by taking a sample of 39 people at Muhammadiyah Junior High School in Bogor. Result Analysis of the results of this study using path analysis. The results of the research include variable self-esteem which directly determines changes in the variable job satisfaction is $31.5 \%$. If through the self-efficacy variable the effect on the job satisfaction variable is $13.5 \%$. So the total effect of self-esteem on job satisfaction is 45.1\%. Self-efficacy variable has a direct effect on Job Satisfaction by $16.9 \%$. For the indirect effect, namely through the variable Self-esteem the effect on Job Satisfaction is $13.6 \%$. So the total effect of the variable self-efficacy on job satisfaction is $30.5 \%$. 


\section{A. PENDAHULUAN}

\section{Latar Belakang Penelitian}

Agar tujuan setiap organisasi dapat tercapai maka sangat dibutuhkan faktor utama yang mendukung berupa Sumber Daya Manusia yang handal. Dari sejumlah data saat ini didapat informasi mengenai jumlah guru di Indonesia hanya 9 juta orang dari total jumlah masyarakat Indonesia.

Guna mencetak Sumber Daya Manusia yang potensial dan berkualitas dewasa ini tidaklah sederhana, permasalahannya tersedianya guru yang profesional dan memiliki kompetensi tinggi seperti yang diamanatkan dalam Undang-Undang serta diinginkan oleh semua pihak, hingga saat ini masih belum bisa terwujud menjadi kenyataan.

Jumlah Beban kerja guru dalam memenuhi beban mengajar guru paling sedikit ditetapkan 24 (dua puluh empat) jam tatap muka dan paling banyak 40 (empat puluh) jam tatap muka dalam 1 (satu) minggu pada satu atau lebih satuan pendidikan, proses penataan ulang agar rasio, kualifikasi akademik, distribusi, dan komposisi guru sesuai dengan kebutuhan riil masingmasing satuan pendidikan, hal ini jelas bahwa pembinaan Sumber Daya Manusia pada pendidikan formal, sangat tergantung pada guru sebagai ujung tombak penyelenggara pendidikan. Guru wajib mempunyai kualitas yang tinggi, karena guru merupakan komponen inti dan pengambil peran dalam proses pendidikan disekolah guna mencetak generasi yang unggul dan berkualitas.

Kinerja guru, sering dijadikan salah satu penyebab menurunnya mutu sekolah. Oleh karena itu. Untuk meningkatkan kinerja guru dalam mengajar, semua guru harus memenuhi tuntutan yang diatur dalam undang-undang Nomor 20 Tahun 2003 tentang Sistem Pendidikan Nasional Bab XI pasal 39 ayat (1), yaitu : tenaga kependidikan bertugas melaksanakan administrasi, pengelolaan, pengembangan, pengawasan, dan pelayanan teknis untuk menjunjung proses pendidikan pada satuan pendidikan

Berkaitan dengan desentralisasi pendidikan melalui penerapan MBS (Manajemen Berbasis Sekolah) sebagai upaya peningkatan kualitas pendidikan disekolah. SMP Muhammadiyah Kota Bogor merupakan salah satu sekolah yang terus berusaha meningkatkan kualitas pendidikan dengan menerapkan MBS, dimana sekolah memiliki otonomi dalam pengelolaan manajerial sekolah dengan mengikutsertakan masyarakat dan pemerintah daerah.

Untuk menanggulangi permasalahan tersebut diperlukan peningkatan kinerja, dimana kinerja yang baik ini merupakan tanggung jawab dari seluruh pihak sekolah, termasuk para guru tatausaha sebagai salah satu unit kerja, dimana mereka berhubungan dan bersinggungan langsung dengan siswa.

Kinerja guru merupakan hasil atau prestasi kerja guru yang dinilai dari segi kualitas maupun kuantitas berdasarkan standar kerja yang ditentukan oleh pihak organisasi. Kinerja yang baik adalah kinerja yang optimal, yaitu kinerja yang sesuai standar organisasi dan mendukung tercapainya tujuan organisasi tersebut. Organisasi yang baik adalah organisasi yang berusaha meningkatkan kemampuan sumber daya manusianya, karena hal itu merupakan faktor kunci untuk meningkatkan kinerja para gurunya.

Ketidak efektifan suatu organisasi dapat disebabkan oleh berbagai faktor internal dan eksternal. Salah satu faktor internal yang dikaitkan dengan pencapaian kinerja adalah aspek sikap dan perilaku pekerja terhadap pekerjaan dan lingkungannya. Pengetahuan para manajer mengenai sikap dan perilaku bawahannya tersebut bermanfaat untuk desain pengendalian yang tidak menimbulkan perilaku disfungsional, Hopwood dalam Aries (2011 45), dalam hal ini antara lain terkait dengan aspek Kepuasan kerja.

Kepuasan kerja pada dasarnya merupakan seperangkat perasaan guru tentang menyenangkan atau tidaknya pekerjaan mereka. Seorang guru yang merasakan kepuasaan kerja akan melaksanakan pekerjaan dengan lebih baik, sebaliknya guru yang tidak memperoleh kepuasan kerja tidak akan pernah mencapai kematangan psikologi yang akan menyebabkan frustasi dan merosotnya kinerja. 
Dikarenakan Kepuasan kerja merupakan faktor penting untuk mendapatkan hasil kerja yang optimal, maka manajemen sekolah tidak boleh membiarkan kepuasan yang dimiliki oleh guru terus mengalami penurunan, karena seorang merasakan kepuasan dalam mengajar tentunya ia akan berupaya semaksimal mungkin dengan segenap kemampuan yang dimilikinya untuk menyelesaikan tugas mengajarnya. Dengan demikian produktivitas dan hasil kerja kerja guru akan meningkat secara optimal.

Banyak hal yang dapat mempengaruhi kinerja dan kepuasan kerja seorang guru baik yang berasal dari internal maupun eksternal. ada dua faktor yang mempengaruhi kinerja seseorang guru, yaitu faktor individual dan faktor lingkungan. Faktor individual meliputi, energi fisik dan mental yang digunakan menyelesaikan tugas, sifat pribadi, dan persepsi peran. Faktor lingkungan meliputi kondisi fisik, peralatan, waktu, material, pendidikan, supervisi, desain organisasi, pelatihan dan sebagainya (Byars \& Rue, 2009).

Efikasi diri merupakan salah satu faktor internal yang mempengaruhi kepuasan dan kinerja, dimana efikasi diri merupakan keyakinan individu untuk memotivasi dirinya sendiri dalam melaksanakan tugas-tugas spesifik yang terdiri dari pertimbangan efikasi diri dan keyakinan diri teknologi informasi. Sedangkan konsekuensi dari self-efikasi merupakan perilaku (kinerja) dan sikap yang terdiri dari kepuasan kerja dan komitmen organisasi (Novan, 2011).

Efikasi seseorang sangat menentukan seberapa besar usaha yang dikeluarkan dan seberapa individu bertahan dalam menghadapi rintangan dan pengalaman yang menyakitkan. Semakin kuat persepsi efikasi diri semakin giat dan tekun usaha-usahanya. Ketika menghadapi kesulitan, individu mempunyai keraguan yang besar tentang kemampuannya akan mengurangi usaha-usahanya atau menyerah sama sekali. Sedangkan mereka yang mempunyai perasaan efikasi yang kuat menggunakan usaha yang lebih besar untuk mengatasi tantangan. Dengan kata lain, usaha manusia untuk mencapai sesuatu dan untuk mewujudkan keberadaan diri yang positif, memerlukan perasaan keunggulan pribadi (sense of personal efikacy) yang optimis. Hal ini dikarenakan oleh realitas sosial yang biasanya penuh dengan kesulitan sehingga orang harus memiliki perasaan keunggulan pribadi yang kuat untuk mempertahankan usaha yang teguh dalam menghadapi kesulitan dan rintangan, maka di sinilah peranan keyakinan diri diperhitungkan.

Persepsi efikasi yang lemah merupakan hambatan internal menuju kemajuan dan menghalangi kemampuan untuk mengatasi hambatan eksternal secara efektif. Efikasi diri yang rendah dapat menghalangi usaha meskipun individu memiliki ketrampilan dan menyebabakna mudah putus asa. Individu mungkin mengetahui kalau tindakanya akan menghasilkan akibat tertentu, namun tidak yakin terhadap kemampuannya melakukan tindakan tersebut.

Selain efikasi diri, keyakinan diri pun diduga merupakan faktor yang dapat mempengaruhi pencapaian kinerja seseorang. Dimana Keyakinan diri adalah kecenderungan seseorang memandang dirinya memiliki kemampuan untuk mengatasi tantangan dalam kehidupan dan berhak untuk berbahagia.

Faktor-faktor yang mempengaruhi keyakinan diri sebagai berikut :

Adanya status sebagai komunitas etnis minoritas. Penelitian menyebutkan bahwa kondisi mayoritas dan minoritas memudahkan munculnya prasangka dan diskriminasi antar kelompok etnis. Individu kelompok etnis mayoritas akan memiliki keyakinan diri lebih tinggi.

Posisi individu dalam kelas sosial, berdasarkan beberapa penelitian juga menyebabkan perbedaan keyakinan diri individu.

Jenis kelamin juga merupakan faktor yang mempengaruhi keyakinan diri. Umumnya wanita cenderung memiliki keyakinan diri yang rendah dibandingkan pria (Emler, 2011).

Memperhatikan faktor-faktor yang berpengaruh pada keyakinan diri tersebut, maka karakteristik individu dengan keyakinan diri tinggi adalah memiliki rasa percaya diri yang bagus, memiliki kemampuan untuk memecahkan masalah lebih bagus dibandingkan dengan perasaan khawatir terhadap masalah tersebut, memiliki kemampuan untuk mengambil resiko terhadap keputusan yang dibuat dan menjaga serta memelihara dirinya sendiri. 
Berdasarkan uraian permasalahan di atas, maka penulis tertarik untuk melakukan penelitian mengenai "Pengaruh Harga diri dan Efikasi diri Terhadap Kepuasan Kerja Serta Implikasinya Terhadap Kinerja Guru SMP Muhammadiyah Kota Bogor.

\section{B. KAJIAN LITERATUR Harga Diri}

Nilai diri sendiri berdasarkan hasil evaluasi diri secara keseluruhan biasa kita kenal dengan harga diri. Bagaimana orang lain memperlakukan kita pada kondisi nyata hal inilah yang membentuk perasaan - perasaan harga diri. Pengurkuran harga diri melalui pernyataan positif maupun negatif. Pernyataan positif pada survey harga diri adalah "saya merasa bahwa saya adalah seseorang yang sangat berarti, seperti orang lainnya, sedangkan pernyataan pernyatan yang negatif adalah "saya merasa bahwa saya tidak memiliki banyak hal untuk dibanggakan" (Kreitner dan Kinicki, 2007 : 165)

"Indikator - indikator untuk pengukuran harga diri ini antara lain" (Hary, $2007: 5)$ :

1. Karyawan merasa dihargai dalam menjalankan pekerjaannya

2. Karyawan mengacu pada hasil akhir pekerjaannya

3. Karyawan berusaha untuk menghargai pekerjaannya

4. Karyawan merasa puas atau senang akan hasil kerjanya

5. Karyawan tidak mencela pekerjaan rekan sekerja

6. Karyawan tidak mementingkan diri sendiri

7. Karyawan tidak suka mengolok - olok rekan sekerja

8. Karyawan tidak malu untuk membuka diri terhadap rekan sekerja

9. Karyawan berani mengambil resiko demi kemajuan

10. Karyawan berusaha untuk membuat keputusan yang bijaksana

\section{Efikasi Diri}

"Menurut Ivancevich at el. (2006:97) bahwa: Efikasi diri berhubungan dengan harga pribadi mengenai kompetensi dan kemampuan diri. Secara spesifik, hal tersebut merujuk pada harga seseorang terhadap kemampuan untuk menyelesaikan suatu tugas secara berhasil". Seseorang yang memiliki tingkat harga diri yang tinggi akan memiliki keyakinan yang tinggi juga dalam kemampuan kinerja mereka. 3 dimensi dalam konsep harga diri antara lain yaitu besarnya, kekuatan, dan generalitas. Besarnya merujuk pada tingkat kesulitan tugas yang diyakini dapat ditangani oleh individu. Kekuatan merujuk pada apakah harga berkenaan dengan besarnya harga diri kuat atau lemah. Generalitas merujuk pada seberapa luas situasi dimana harga terhadap kemampuan tersebut berlaku

"Menurut Bandura dalam Luthan (2006:26), efikasi diri pada diri tiap individu akan berbeda antara satu individu dengan yang lainnya berdasarkan tiga dimensi". Berikut adalah tiga dimensi tersebut.

1. Dimensi tingkat level (level)

dimensi ini berkaitan dengan derajat kesulitan tugas ketika individu merasa mampu untuk melakukannya. Apabila individu dihadapkan pada tugas-tugas yang disusun menurut tingkat kesulitannya, maka efikasi diri individu mungkin akan terbatas pada tugas-tugas yang mudah, sedang, atau bahkan meliputi tugas-tugas yang paling sulit, sesuai dengan batas kemampuan yang dirasakan untuk memenuhi tuntutan perilaku yang dibutuhkan pada masing-masing tingkat. Dimensi ini memiliki implikasi terhadap pemilihan tingkah laku yang dirasa mampu dilakukannya dan menghindari tingkah laku yang berada di luar batas kemampuan yang di rasakannya.

2. Dimensi kekuatan (strength)

Dimensi ini berkaitan dengan tingkat kekuatan dari harga atau pengharapan individu mengenai kemampuannya. Pengharapan yang lemah mudah digoyahkan oleh pengalaman-pengalaman yang tidak mendukung. Sebaliknya, pengharapan yang mantap mendorong individu tetap bertahan dalam usahanya. Meskipun mungkin ditemukan pengalaman yang kurang menunjang. Dimensi ini biasanya berkaitan langsung dengan dimensi level, yaitu makin tiggi level taraf kesulitan tugas, makin lemah harga yang dirasakan untuk menyelesaikannya. 
3. Dimensi generalisasi (geneality)

Dimensi ini berkaitan dengan luas bidang tingkah laku yang mana individu merasa yakin akan kemampuannya. Individu dapat merasa yakin terhadap kemampuan dirinya. Apakah terbatas pada suatu aktivitas dan situasi tertentu atau pada serangkain aktivitas dan situasi yang bervariasi.

Dari uraian di atas, dapat disimpulkan bahwa dimensi-dimensi, efikasi diri adalah tingkat (level), dimensi kekuatan (strenght), dan dimensi generalisasi (generality)

\section{Kepuasan Kerja}

"Luthans (2006 : 230), kepuasan kerja sebagai keadaan emosional yang positif yang dihasilkan dari penghargaan atas pekerjaan seseorang atau pengalaman kerja seseorang. Lebih lanjut Luthans juga menegaskan, bahwa kepuasan kerja merupakan hasil persepsi para karyawan tentang seberapa baik pekerjaan seseorang dalam memberikan segala sesuatu yang dipandang sebagai suatu yang penting melalui hasil kerjanya. Istilah kepuasan kerja merujuk pada sikap (reaksi emosional) seorang individu terhadap pekerjaannya"

Dimensi kepuasan kerja :

Luthans (2006:230), menyatakan terdapat lima faktor yang mempengaruhi kepuasan kerja, yaitu :

1. Pekerjaan itu sendiri

Work it self adalah sifat menyeluruh dari pekerjaan itu sendiri yang merupakan factor penentu utama dalam kepuasan kerja. Pekerjaan mempengaruhi kepuasan kerja melalui rancangan jabatan. Pekerjaan itu dipengaruhi oleh elemen-elemen seperti skill variety, task identity, task significant, autonomy and feed back dari pekerjaan itu sendiri yang memberikan kontribusi terhadap kepuasan kerja.

2. Pengawasan

Supervision merupakan pengawasan langsung yang dilaksanakan oleh seorang atasan terhadap hasil pekerjaan yang dilakukan oleh bawahannya supervisor yang baik harus mau menghadapi pekerjaan bawahnya dan dapat menjadi figur yang disenangi oleh bawahannya.

3. Promosi

Promotion adalah perpindahan pegawai dari satu jabatan ke jabatan yang lain yang mempunyai tingkatan organisasional, tanggung jawab dan pembayaran yang lebih tinggi.

4. Upah atau gaji

Pay dapat diartikan sebagai balas jasa berupa uang yang diberikan perusahaan kepada seorang pegawai sebagai imbalan atas tenaga, pemikiran dan waktu yang telah diberikan kepada perusahaan.

5. Kondisi kerja

Coworkers merupakan interaksi social yang terjadi antara sesama rekan sekerja dalam lingkungan pekerjaan baik sebagai sesama pekerja, atasan dan bawahan dan antara rekan sekerja yang berbeda jenis pekerjaannya

\section{Kinerja Guru}

Istilah kinerja berasal dari kata job performance atau actual performance (prestasi kerja atau prestasi sesungguhnya yang dicapai oleh seseorang). Pengertian kinerja individual adalah hasil kerja secara kualitas dan kuantitas yang dicapai oleh seorang karyawan dalam melaksanakan tugasnya sesuai dengan tanggungjawab yang diberikan kepadanya. Gomes (2007:142) mengemukakan bahwa kinerja adalah catatan outcome yang dihasilkan dari fungsi suatu pekerjaan atau kegiatan tertentu selama periode waktu tertentu.

Penilaian terhadap kinerja karyawan yang berdasarkan deskripsi perilaku yang spesifik, maka ada beberapa dimensi atau kriteria dari kinerja yang digunakan oleh peneliti dalam penelitian ini, sebagaimana konsep yang dikemukakan Gomes (2007:142), di antaranya :

1. Kuantitas kerja

2. Kualitas kerja

3. Pengetahuan pekerjaan 


\author{
4. Kreativitas \\ 5. Kerjasama \\ 6. Dependability \\ 7. Inisiatif \\ 8. Kualitas personal
}

ISSN (print) : 2598-9545 \& ISSN (online) : 2599-171X

\title{
- $\quad$ Pengaruh Harga Diri Terhadap Kepuasan Kerja
}

Para peneliti mendifinisikan organization based harga diri (OBSE) atau harga diri dalam organisasi sebagai nilai yang dimiliki oleh individu atas dirinya sendiri sebagai anggota organsasi yang bertindak dalam konteks organisasi. Orang yang memiliki skor OBSE tinggi cenderung memandang diri mereka sendiri sebagai orang yang penting, berharga, berpengaruh dan berarti dalam konteks organisasi yang mempekerjakan mereka (Kreitner dan Kinicki, 2007). Dengan demikian jika seseorang merasa dirinya begitu penting, berharga dan berpengaruh maka timbul perasaan kepuasan atas pekerjaan yang dilakukannya karena yang dilakukannya berhasil dan menciptakan hasil yang optimal. Meta analisis yang dilakukan oleh Judge \& Bono (2008) menemukan ada hubungan positif antara harga diri dan kepuasan kerja.

\section{- $\quad$ Pengaruh Efikasi Diri Terhadap Kepuasan Kerja}

Efikasi diri merupakan kepercayaan terhadap kemampuan seseorang untuk menjalankan tugas. Orang yang percaya diri dengan kemampuannya cenderung untuk berhasil, sedangkan orang yang selalu merasa gagal cenderung untuk gagal. Efikasi diri berhubungan dengan kepuasan kerja dimana jika seseorang memiliki efikasi diri yang tinggi maka cenderung untuk berhasil dalam tugasnya sehingga meningkatkan kepuasan atas sesuatu yang dikerjakannya. Meta analisis yang dilakukan oleh Judge \& Bono (2008) menemukan ada hubungan positif antara kepuasan kerja dan efikasi diri .

Bandura (2008) mengungkapkan bahwa individu yang memiliki self efficay tinggi akan mencapai suatu kinerja yang lebih baik karena individu ini memiliki motivasi yang kuat, tujuan yang jelas, emosi yang stabil dan kemampuannya untuk memberikan kinerja atas aktivitas atau perilaku dengan sukses. Kinerja yang baik dari seorang karyawan dengan efikasi diri tinggi menunjukkan tingkat kepusan kerja yang dialami oleh karyawan tersebut juga tinggi.

Berbeda individu dengan efikasi diri rendah yang akan cenderung tidak mau berusaha atau lebih menyukai kerjasama dalam situasi yang sulit dan tingkat kompleksitas tugas yang tinggi (Lee \& Babko, 2008). Hasil penelitian Bandura (dalam Paulus Joko Sigiro dan Suyono, 2011) ketika menerima umpan balik yang negative, individu yang memiliki efikasi diri yang tinggi akan merespon dengan meningkatkan usaha dan motivasi sedangkan individu dengan efikasi diri yang rendah akan cenderung rendah diri dan menyebabkan menurunnya kinerja individu tersebut. Maka dari pendapat di muka dapat disimpulkan bahwa individu dengan efikasi diri tinggi akan mengalami kepuasan kerja yang tingi, sedangkan individu dengan efikasi diri yang rendah akan mengalami tingkat kepuasan kerja yang rendah pula.

\section{- $\quad$ Pengaruh Kepuasan Kerja terhadap Kinerja Guru}

Suatu studi empiris mengenai kepuasan kerja yang dilakukan oleh Baron, mengindikasikan bahwa kondisi kerja dapat membantu meningkatkan minat kerja, promosi dan meminimalisir konflik antar karyawan yang semuanya itu akan mengarah pada kepuasan kerja karyawan. Menurut Lum, suatu program perbaikan kualitas dapat meningkatkan kepuasan kerja karyawan, antara lain melalui minat kerja yang meningkat, hubungan baik dengan manajemen atau sesama karyawan, keamanan kerja, peningkatan tanggung jawab, peningkatan gaji, kesempatan untuk promosi, kejelasan peran dan partisipasi yang semakin meningkat dalam pengambilan keputusan. Studi yang dilakukan oleh Madu, dalam menunjukkan hubungan yang signifikan antara kepausan kerja karyawan dengan kinerja, baik untuk perusahaan kecil maupun besar. (Bambang Guritno \& Waridin, 2005).

Secara historis, pegawai yang mendapatkan kepuasan kerja akan melaksanakan pekerjaan dengan baik. Masalahnya adalah terdapatnya karyawan yang kepuasan kerjanya tinggi tidak 
menjadi karyawan yang produktivitasnya tinggi. Banyak pendapat mengemukakan bahwa kepuasan kerja yang lebih tinggi, terutama yang dihasilkan oleh kinerja, bukan sebaliknya. Kinerja lebih baik mengakibatkan penghargaan lebih tinggi. Bila penghargaan tersebut dirasakan adil dan memadai, maka kepuasan kerja karyawan akan meningkat karena mereka menerima penghargaan dalam proporsi yang sesuai dengan kinerja mereka. Kondisi kepuasan atau ketidakpuasan kerja tersebut menjadi umpan balik yang akan memengaruhi kinerja di waktu yang akan datang. Jadi, hubungan kinerja dan kepuasan kerja menjadi suatu sistem yang berlanjut. Menurut Strauss dan Sayles kepuasan kerja juga penting untuk aktualisasi dini. Karyawan yang tidak memperoleh kepuasan kerja tidak akan pernah mencapai kematangan psikologis dan pada gilirannya akan menjadi frustasi. Karyawan seperti ini akan sering melamun, mempunyai semangat kerja rendah, cepat lelah dan bosan, emosinya tidak stabil, sering absen dan tidak melakukan kesibukan yang tidak ada hubungan dengan pekerjaan yang harus dilakukan. (Parwanto \& Wahyudin, 2005).

Kepuasan kerja merupakan salah satu ukuran kualitas kehidupan dalam organisasi dan akan menjadi prediksi yang tidak baik apabila kepuasan kerja tidak menyebabkan peningkatan kinerja. Indikasi kepuasan kerja, biasanya dikaitkan dengan tingkat absensi, turnover, dimana kedua hal tersebut dapat memunculkan biaya yang tinggi dalam organisasi, sehingga perusahaan sangatlah beralasan secara ekonomi untuk memberikan perhatian terhadap kepuasan kerja karena sangat memengaruhi kinerja karyawan dan efektivitas organisasi (Lawler III, 2008)

Hipotesis yang ditetapkan berdasarkan pemikiran-pemikiran tersebut diatas adalah sebagai berikut :

1. Terdapat pengaruh harga diri terhadap kepuasan kerja guru SMP Muhammadiyah Kota Bogor secara parsial

2. Terdapat pengaruh efikasi diri terhadap kepuasan kerja guru SMP Muhammadiyah Kota Bogor secara parsial

3. Terdapat pengaruh kepuasan kerja terhadap kinerja guru SMP Muhammadiyah Kota Bogor secara parsial

4. Terdapat pengaruh harga diri dan efikasi diri terhadap kepuasan kerja guru SMP Muhammadiyah Kota Bogor secara simultan

\section{METODOLOGI PENELITIAN}

\section{Jenis Data}

Penelitian ini merupakan penelitian dalam bidang Manajemen Sumber Daya Manusia. Penelitian ini dilakukan untuk mengetahui harga diri dan Efikasi diri pengaruhnya terhadap Kepuasan Kerja serta implikasinya terhadap Kinerja guru.

Berdasarkan pertimbangan tujuan penelitian, maka penelitian ini bersifat deskriptif dan verifikatif. Menurut Sugiyono (2013:11) penelitian deskriptif adalah penelitian yang dilakukan untuk mengetahui nilai variabel mandiri, baik satu variabel atau lebih (independent) tanpa membuat perbandingan, atau menghubungkan dengan variabel yang lain. Disamping itu digunakan metode verifikatif yang pada dasarnya digunakan untuk mengetahui hubungan antara variabel melalui metode penelitian yang telah dirumuskan.(Sugiyono, 2013:11).

Untuk melaksanakan penelitian verifikatif tersebut digunakan metode survey yang telah dirumuskan. Dimana menurut Kerlinger dalam Sugiyono (2013:7) penelitian survey adalah penelitian yang dilakukan pada populasi besar maupun kecil, tetapi data yang dipelajari adalah data dari sampel yang diambil dari populasi tersebut sehingga ditemukan kejadian-kejadian relatif, distribusi, dan hubungan-hubungan antar variabel sosiologis maupun psikologis.

Populasi Penelitian

Populasi adalah wilayah generalisasi yang terdiri atas obyek/subyek yang mempunyai kualitas dan karakteristik tertentu yang ditetapkan oleh peneliti untuk dipelajari dan kemudian ditarik kesimpulannya (Sugiyono, 2013:72). Total Guru SMP Muhammadiyah Kota Bogor 
sebanyak 35 orang sedangkan yang menjadi populasi dalam penelitian ini yaitu seluruh guru yang ada pada SMP Muhammadiyah Kota Bogor.

- Teknik Penarikan Sampel

Teknik penentuan sampel dalam penelitian ini adalah menggunakan teknik sampling jenuh. Sampling jenuh adalah teknik penentuan sampel bila semua anggota populasi digunakan sebagai sampel. Istilah lain sampel jenuh adalah sensus (Sugiyono, 2013).

\section{HASIL DAN PEMBAHASAN}

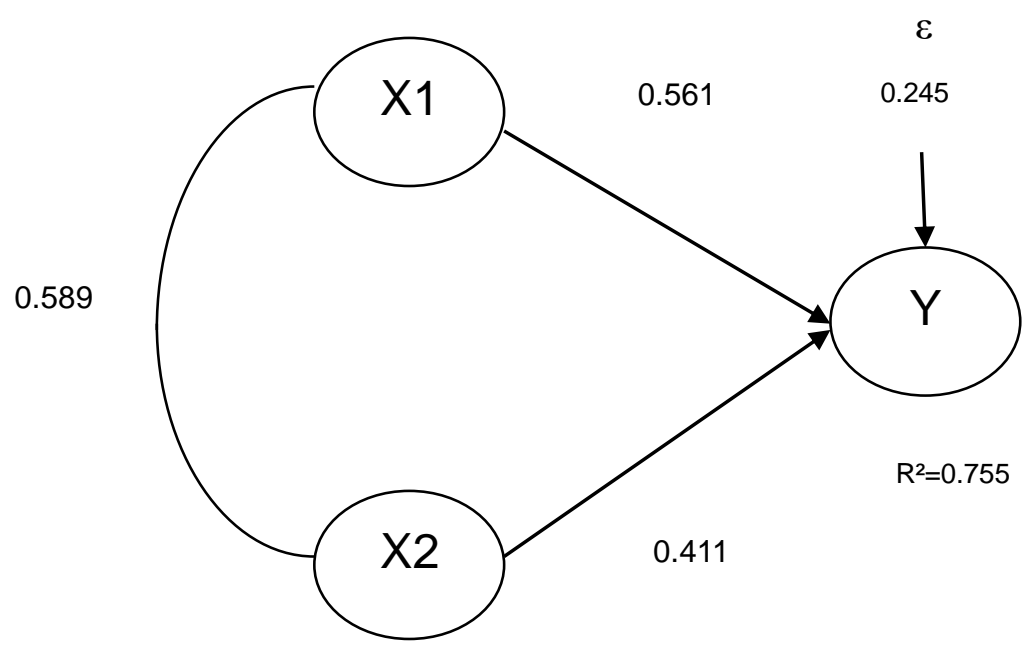

Gambar 1 Koefisien Jalur

Berdasarkan gambar diperoleh besaran koefisien jalur antar variabel penelitian yang dapat di lihat pada tabel sebagai berikut :

Tabel 1

Hasil Perhitungan Jalur

\begin{tabular}{|l|c|}
\hline \multicolumn{1}{|c|}{ Variabel } & Koefisien Jalur \\
\hline Harga diri $\left(\mathrm{X}_{1}\right)$ & 0,561 \\
\hline Efikasi diri $\left(\mathrm{X}_{2}\right)$ & 0,411 \\
\hline
\end{tabular}

Sumber : Hasil perhitungan statistik

Tabel di atas menggambarkan hasil perhitungan jalur, bahwa variabel X1 mempunyai koefisien jalur sebesar 0,561, Variabel X2 mempunyai koefisien jalur sebesar 0,411 Hasil tersebut dapat digambarkan dalam persamaan jalur sebagai berikut;

$$
Y=0,561 X_{1}+0,411 X_{2}+C
$$

Dimensiana :

$Y \quad=$ Kinerja Guru

$\mathrm{X} 1=$ Harga diri

$\mathrm{X} 2=$ Efikasi diri 
Besarnya pengaruh dari masing-masing variabel bebas terhadap variabel terikat baik pengaruh langsung (Direct Effect) maupun pengaruh tidak langsung (Indirect Effect) dapat di lihat pada tabel berikut ini :

Tabel 2

Pengaruh Langsung dan Pengaruh Tidak Langsung

\begin{tabular}{|c|c|c|c|c|}
\hline \multirow{2}{*}{ Variabel } & \multirow{2}{*}{$\begin{array}{c}\text { Pengaru } \\
\mathbf{h} \\
\text { langsun } \\
\mathbf{g}\end{array}$} & \multicolumn{2}{|c|}{$\begin{array}{l}\text { Pengaruh Tidak } \\
\text { Langsung Melalui }\end{array}$} & \multirow{2}{*}{$\begin{array}{c}\text { Pengaruh } \\
\text { Total }\end{array}$} \\
\hline & & $X_{1}$ & $\mathbf{X}_{2}$ & \\
\hline Harga Diri & $31,5 \%$ & - & $13,6 \%$ & $45,1 \%$ \\
\hline Efikasi Diri & $16,9 \%$ & $13,6 \%$ & - & $30,4 \%$ \\
\hline \multicolumn{4}{|c|}{ Pengaruh Total } & $75,5 \%$ \\
\hline
\end{tabular}

Tabel 3

Pengaruh Harga diri $\left(X_{1}\right)$ terhadap Kepuasan Kerja $(Y)$

\begin{tabular}{|c|c|c|c|}
\hline \multicolumn{3}{|c|}{ Pengaruh Langsung dan Tidak Langsung } & $\begin{array}{c}\text { Besar } \\
\text { Kontribusi }\end{array}$ \\
\hline $\mathrm{X}_{1}$ Langsung & $\left(\rho_{\mathrm{yx} 1}\right)^{2}$ & $(0.561)^{2}$ & 0.315 \\
\hline $\mathrm{X}_{1}$ melalui $\mathrm{X}_{2}$ & $\rho_{\mathrm{y} \times 1}{ }^{*} \mathrm{rX}_{2} \mathrm{X}_{1}{ }^{*} \rho_{\mathrm{yx} 2}$ & $(0.561)^{\star}(0.589)^{\star}(0.411)$ & 0.135 \\
\hline \multicolumn{2}{|c|}{ Total Pengaruh $\mathrm{X}_{\mathbf{1}}$ terhadap $\mathrm{Y}$} & $\mathbf{0 . 4 5 1}$ \\
\hline
\end{tabular}

Sumber : Hasil Perhitungan

Itu berarti variabel Harga diri (X1) secara langsung menentukan perubahan-perubahan variabel Kepuasan Kerja ( $Y$ ) adalah 31,5\%. Jika melalui variabel Efikasi diri (X2) pengaruhnya terhadap variabel Kepuasan Kerja (Y) adalah sebesar 13,6\%. Jadi pengaruh total Harga diri (X1) terhadap Kepuasan Kerja $(Y)$ adalah sebesar $45,1 \%$. Dengan asumsi semakin tinggi tingkat Harga diri seorang guru maka akan semakin tinggi pula tingkat Kepuasan Kerja

Tabel 4

Pengaruh Efikasi diri $\left(\mathrm{X}_{2}\right)$ terhadap Kinerja Guru $(\mathrm{Y})$

\begin{tabular}{|c|c|c|c|}
\hline \multicolumn{3}{|c|}{ Pengaruh Langsung dan Tidak Langsung } & $\begin{array}{c}\text { Besar } \\
\text { Kontribusi }\end{array}$ \\
\hline $\mathrm{X}_{2}$ Langsung & $\left(\rho_{\mathrm{yx} 2}\right)^{2}$ & $(0.411)^{2}$ & 0.169 \\
\hline $\mathrm{X}_{2}$ melalui $\mathrm{X}_{1}$ & $\rho_{\mathrm{yx} 2}{ }^{*} \mathrm{rX}_{1} \mathrm{X}_{2}{ }^{*} \rho_{\mathrm{y} \times 1}$ & $(0.411)^{\star}(0.589)^{*}(0.561)$ & 0.135 \\
\hline \multicolumn{2}{|c|}{ Total Pengaruh $\mathrm{X}_{2}$ terhadap $\mathrm{Y}$} & $\mathbf{0 . 3 0 4}$ \\
\hline
\end{tabular}

Sumber : Hasil Perhitungan

Dapat diartikan bahwa variabel Efikasi diri (X2) memiliki pengaruh secara langsung terhadap Kepuasan Kerja $(\mathrm{Y})$ sebesar 16,9\%. Untuk pengaruh tidak langsung, yakni yang melalui variabel Harga diri (X1) pengaruhnya terhadap Kepuasan Kerja (Y) adalah sebesar 13,6\%. Jadi pengaruh total variabel Efikasi diri (X2) terhadap Kepuasan Kerja (Y) adalah sebesar 30,5\%. Dengan asumsi semakin tinggi Efikasi diri seorang Pegawai maka akan semakin tinggi pula tingkat Kepuasan Kerja.

\section{- Koefisien Determinasi}

\begin{tabular}{|c|c|c|c|c|}
\hline \multicolumn{5}{|c|}{$\begin{array}{c}\text { Tabel } 5 \\
\text { Koefisien Determinasi } \\
\text { Model Summary }\end{array}$} \\
\hline Model & $\mathrm{R}$ & R Square & $\begin{array}{l}\text { Adjusted R } \\
\text { Square }\end{array}$ & $\begin{array}{c}\text { Std. Error of the } \\
\text { Estimate }\end{array}$ \\
\hline 1 & $.869^{\mathrm{a}}$ & .755 & .742 & 3.93312 \\
\hline
\end{tabular}


Koefisien Determinasi merupakan koefisien yang digunakan untuk mengetahui besarnya kontribusi variabel independen terhadap perubahan variabel dependen, sesuai dengan hasil perhitungan total pengaruh langsung dan tidak langsung diperoleh 0,755 dengan demikian kontribusi ketiga variabel tersebut sebesar 75,5\% sedangkan sisanya sebesar $24,5 \%$ merupakan kontribusi variabel lain yang tidak diteliti

\section{- Pengaruh Kepuasan Kerja (Y) Terhadap Kinerja Guru (Z)}

Secara umum, analisis regresi sederhana merupakan studi mengenai ketergantungan variabel terikat dengan satu atau beberapa variabel bebas, dengan tujuan untuk mengestimasi/memprediksi rata-rata populasi atau nilai rata-rata variabel dependen berdasarkan nilai variabel independen yang diketahui. Adapun analisis linier sederhana sendiri secara umum digunakan untuk menganalisis hubungan antara suatu variabel dengan satu atau beberapa variabel bebas (Gujarati dalam Imam Ghozali, 2002 : 42).

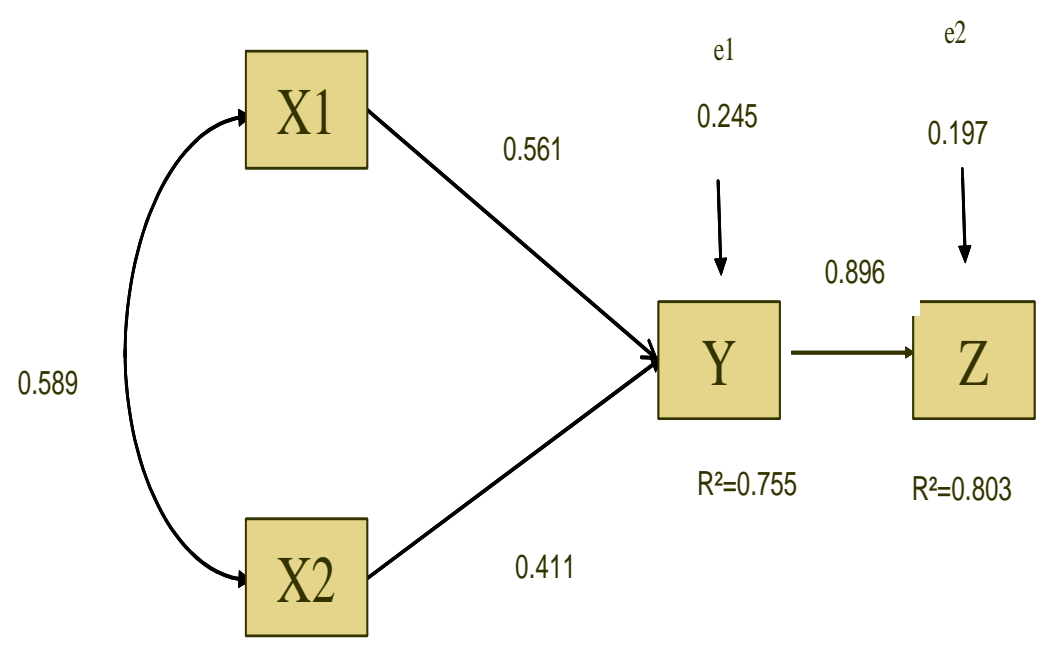

\section{Gambar 2 Pengaruh Y Terhadap Z}

Jika berasumsi bahwa Kepuasan Kerja dapat menjelaskan perubahan-perubahan dari Kinerja Guru, maka dapat ditentukan berapa besarkah dalam presentase perubahanperubahan dari Kinerja Guru (Z) yang bisa dijelaskan oleh variabel Kepuasan Kerja (Y). Berdasarkan hasil Perhitungan SPSS dapat diketahui besarnya Pengaruh Kepuasan Kerja (Y) terhadap Kinerja Guru (Z).

Berdasarkan hasil perhitungan SPSS, maka koefisien jalur Kepuasan Kerja terhadap Kinerja Pegawai dapat dilihat pada tabel berikut ini :

Tabel 6

Koefisien jalur variabel $Y$ terhadap $Z$

Coefficients $^{a}$

\begin{tabular}{|c|c|c|c|c|c|}
\hline \multirow[b]{2}{*}{ Model } & \multicolumn{2}{|c|}{$\begin{array}{l}\text { Unstandardized } \\
\text { Coefficients }\end{array}$} & \multirow{2}{*}{\begin{tabular}{|c|}
$\begin{array}{c}\text { Standardized } \\
\text { Coefficients }\end{array}$ \\
Beta \\
\end{tabular}} & \multirow[b]{2}{*}{$l$} & \multirow[b]{2}{*}{ Sig. } \\
\hline & $B$ & Std. Error & & & \\
\hline $\begin{array}{l}\text { (Constant) } \\
Y\end{array}$ & $\begin{array}{r}14.528 \\
.758\end{array}$ & $\begin{array}{r}3.859 \\
.062 \\
\end{array}$ & .896 & $\begin{array}{r}3.764 \\
12.283\end{array}$ & $\begin{array}{l}.001 \\
.000\end{array}$ \\
\hline
\end{tabular}

a. Dependent Variable: $z$

Sumber : Pengolahan Data, 2020

JIMF (Jurnal IImiah Manajemen Forkamma), Vol.4, No.2, Maret 2021 
Dari hasil diatas, maka dapat diperoleh persamaan regresi seperti berikut ini : $Z=0.896^{*} Y+\varepsilon$

Tabel 7

Koefisien Determinasi Y terhadap Z Model Summary

\begin{tabular}{|l|c|r|r|r|}
\hline Model & R & R Square & $\begin{array}{c}\text { Adjusted R } \\
\text { Square }\end{array}$ & $\begin{array}{c}\text { Std. Error of } \\
\text { the Estimate }\end{array}$ \\
\hline 1 & $.896^{\mathrm{a}}$ & .803 & .798 & 2.94316 \\
\hline
\end{tabular}

a. Predictors: (Constant), y

Pengaruh Kepuasan Kerja (Y) terhadap Kinerja Guru (Z) secara simultan ditunjukkan oleh koefisien determinasi ganda $\left(R^{2}\right)$, sebagaimana terlihat pada kolom $R$ Square pada tabel di atas. Koefisien ganda $\left(R^{2}\right)$ ini menunjukkan proporsi atau presentase variasi total dalam variabel dependen $(Z)$ yang dijelaskan oleh variabel independen $(Y)$ secara simultan. Dengan menggunakan nilai $\mathrm{R}^{2}$ ini dapat ditafsirkan secara simultan pengaruh Kepuasan Kerja ( $\mathrm{Y}$ ) terhadap Kinerja Guru (Z) adalah sebesar 80,3\%, sedangkan sisanya sebesar 19,7\% Kinerja Guru (Z) disebabkan oleh variabel-variabel lain diluar variabel independen tersebut yang tidak dilibatkan dalam penelitian ini, seperti variabel-variabel motivasional, Locus of Control, Kepemimpinan dan lain-lain

\section{Kesimpulan dan Saran}

\section{Kesimpulan}

1. Berdasarkan hasil perhitungan SPSS, dapat disimpulkan bahwa Harga Diri memiliki pengaruh positif dan signifikan terhadap Kepuasan Kerja pada SMP Muhammadiyah Kota Bogor. Besarnya pengaruh Harga Diri secara parsial terhadap Kepuasan Kerja adalah $45,1 \%$.

2. Berdasarkan hasil perhitungan SPSS, dapat disimpulkan bahwa Efikasi Diri memiliki pengaruh positif dan signifikan terhadap Kepuasan Kerja. Besarnya pengaruh Efikasi Diri secara parsial terhadap Kepuasan Kerja adalah 30,5\%.

3. Berdasarkan hasil perhitungan SPSS, dapat disimpulkan bahwa Harga Diri dan Efikasi Diri memiliki pengaruh yang signifikan terhadap Kepuasan Kerja. Besarnya pengaruh Harga Diri dan Efikasi Diri secara simultan terhadap Kepuasan Kerja adalah 75,5\%.

4. Berdasarkan hasil perhitungan SPSS, dapat disimpulkan bahwa Kepuasan Kerja memiliki pengaruh positif terhadap Kinerja Guru Besarnya pengaruh Kepuasan Kerja secara parsial terhadap Kinerja Pegawai adalah 80,3\%.

\section{Saran}

1. Harga Diri memiliki pengaruh yang signifikan terhadap kepuasan kerja untuk itu harus ada upaya untuk meningkatkan Harga Diri dengan cara taat dan patuh terhadap aspek-aspek yang berkaitan dengan harga diri.

2. Efikasi Diri mempunyai pengaruh yang signifikan terhadap kepuasan kerja ini hendaknya organisasi memperhatikan pelaksanaan belajar dan mengajar agar semua perhatian difokuskan dengan rekan-rekan karena masing-masing kepuasan kerja mempunyai tugasnya masing-masing.

3. Organisasi harus mempertahankan hal-hal yang berkaitan dengan Harga Diri dan Efikasi Diri karena dalam penelitian ini Harga Diri dan Efikasi Diri memiliki pengaruh yang signifikan terhadap kepuasan kerja dan berdampak pada kinerja guru yang tinggi.

4. Kepuasan kerja memiliki pengaruh yang positif terhadap Kinerja guru oleh sebab itu organisasi harus mempertahankannya dan menaikkan indikator yang memiliki bobot yang terkecil dengan cara mempererat kerja sama antar guru. 


\section{DAFTAR PUSTAKA}

Aikaterini Gkolia.2014. Investigate the relation between job satisfaction and selfefficacyexperienced by general employees and teachers, as it rises through literaturereview

Bandura, Albert \& Locke, Edwin. A. 2005. Negative Self-Efficacy and Goal Effects Revisited. Journal of Applied Psychology. Vol. 88, No. 1, 87-99

Baron, RA., \& Byrne R. 2004. Psikologi Sosial Jilid 1 (Alih Bahasa oleh Ratna Djuwita, Melania Meitty Parman, Dyah Yasmina \& Lita Lunanta). Jakarta: Penerbit Erlangga.

Bernardin, H, John and Russel, E,A, 2003, Human Resources Management: An Experiental Approach, Singapore, Mc Graw-Hill International Editions

Brockner, J. 2008. Self-esteem at work: Research, theory, and practice. Lexington, MA: Lexington Books

Brown, B,L., 2001. Self-Efficacy Beliefs and Career Develoment, http://www.ed.gov/databases/ERIC-Digets/ed.

Byars, L Lylod and Lesli W Rue.2008. Human Resource Management, 7 edition.New York : Mc Graw - Hill.

Cervone, D., dan Peake, P.K. 2006. Anchoring, Efficacy, and Action: The Influence of Judgemental Heuristics on Self-Efficacy Judgement and Behavior. Journal of Personality and Social Psychology, Vol.50, 492-501

Dessler, Gary. 2006. Manajemen Personalia. Edisi Ketiga. Jakarta: Erlangga.

Engko, Cecilia. 2008. Pengaruh Kepuasan Kerja Terhadap Kinerja Individual Dengan Self Esteem dan Self Efficacy Sebagai Variabel Intervening. Journal Bisnis dan Akuntansi Vol. 10, No. 1, April hal-1-12.

Erez, A. Dan TA Judge. 2001. Relationship of Core Self Evaluations to Goal Setting, Motivation, and Performance. Journal of Applied Psychology. Vol. 86 No. 6, hlm 1270-1279.

Ertanto, Dwi Yayan \& Suharnomo. 2010. Pengaruh Gaji Terhadap Kinerja Karyawan Dengan Self Esteem Sebagai Variabel Intervening; Studi Pada PDAM Kabupaten Grobogan. Jurnal.

Feldman, RS. 2003. Social Psychology. New Jersey: Prentice-Hall Inc.

Gaouzali, Saydam. 2000. Manajemen Sumber daya Manusia (Suatu Pendekatan Mikro). Jakarta : Djambatan.

Gomes, Faustino Cardoso.2003. Manajemen Sumber Daya Manusia. Penerbit Andi.Yogyakarta. Hary. 2007. Membangun Rasa Percaya Diri. WorldPress.com

Hariyanto, Novan. 2001. Analisis Pengaruh Faktor Self Efficacy Terhadap Kinerja, Kepuasan Kerja, dan Komitmen Organisasi Pekerja Jarak Jauh (Teleworkers): Studi Pada Perusahaan Pemberitaan Internet Online di Indonesia. Thesis Universitas Diponegoro Semarang.

http://www.bppsdmk, 2008

Husnawati, Ari. 2006. Analisis Pengaruh Kualitas Kehidupan Kerja Terhadap Kinerja Karyawan Dengan Komitmen dan Kepuasan Kerja Sebagai Variabel Intervening. Thesis Universitas Diponegoro Semarang.

Johan, Rita. 2002. Kepuasan Kerja Pegawai (Guru) dalam Lingkungan Institusi Pendidikan. Jakarta: Universitas Katolik Atma Jaya.

Judge, TA dan JE Bono. 2001. Relationship of Core Self Evaluations Traits Self Esteem, Gemeralized Self Efficacy, Locus of Control and Emotional Stability eith Job 

Psychology. Vol 86 No. $1 \mathrm{hlm}$. 80-92.

Kreitner, R. Dan A. Kinicki. 2007. Perilaku Organisasi. Edisi Kedua. Jakarta: Salemba Empat.

Lawler III, 1998, Job Satisfaction and Expression Of Emotion in Organizations

Lee, C. \& Bobko P.2004, Self Efficacy Beliefs: Comparasion of Five Measures, Journal of Applied Psychology, Vol. 79. no. 6, page. 819-825

Luthans, Fred. 2006. Organizational Behavior. New York: McGraw-Hill.

Mangkunegara, anwar prabu. 2007. Evaluasi Kinerja SDM. PT Refika Aditama. Bandung

Mangkuprawira, S. 2009. Bisnis, Manajemen, dan Sumberdaya Manusia. Bogor : IPB Press.

Martin C. S. Wong.2012. The Impact of Leadership Programme on Self-Esteemand SelfEfficacy in School: A Randomized Controlled Trial

Mathis dan Jackson. 2009. Manajemen Sumber Daya Manusia, Edisi Pertama,. Salemba Empat, Jakarta

Mondy, R.W \& noe, M.R 2005. Human Resource Management ( $9^{\text {th }}$ Ed). New Jersey. Pearson Education, Inc, Upper Saddle River.

Rivai, 2005, Pengaruh Kepuasan gaji, Kepuasan Kerja dan Komitmen Organisasi Terhadap Intensi Keluar: Pengujian empiris Model Turnover Lum et al , Jurnal Bisnis dan Akuntansi, April , $335-352$

Robbins, Stephen. P. 2007. Organizational Behavior. New Jersey: Prentice Hall.

Schyns, B., dan GV Collani. 2002. A New Occupational Self Efficacy Scale and its Relation to Personality Contructs and Organizational Variables. European Journal of Work and Organizational Psychology. 11 (2). HIm 219-241.

Schunk, D. H .2013.. Self-Efficacy, Motivation, and Performance

Sunardi, N., Lesmana, R., Kartono, K., \& Rudy, R. (2020). Peran Manajemen Keuangan dan Digital Marketing dalam Upaya Peningkatan Omset Penjualan bagi Umkm Pasar Modern Intermoda Bsd City Kota Tangerang Selatan di Tengah Pandemi Covid19. Jurnal Abdi Masyarakat Humanis, 2(1).

Sunardi, N., Lesmana, R., Tumanggor, M., \& Kadim, A. (2019). Implementasi IImu Manajemen dalam Mewujudkan Pembangunan Masjid Raya Abdul Kadim, Yayasan Ar-Rohim, Kab. Musi Banyuasin, Propinsi Sumatra Selatan. Jurnal Abdi Masyarakat Humanis, 1(1).

Sudjana. 2002. Metoda Statistika. Bandung: Tarsito.

Sugiyono. 2013. Statistika Untuk Penelitian. Bandung: Alfabeta. . 2013. Metode Penelitian Bisnis. Bandung: Alfabeta.

W. Gulo, 2002, Metodologi Penelitian, PT. Grasindo, Jakarta

Wexley, Kenneth N. dan Yulk, Gary A., 2003, Perilaku Organisasi dan Psikologi Personalia. Edisi Terjemahan, Cetakan Ketiga, Rineka Cipta, Jakarta 